2003-01-01

\title{
Farm-level pesticide use in Bangladesh: determinants and awareness
}

\author{
Rahman, Sanzidur
}

http://hdl.handle.net/10026.1/4033

10.1016/s0167-8809(02)00089-0

Agriculture Ecosystems \& Environment

Elsevier BV

All content in PEARL is protected by copyright law. Author manuscripts are made available in accordance with publisher policies. Please cite only the published version using the details provided on the item record or document. In the absence of an open licence (e.g. Creative Commons), permissions for further reuse of content should be sought from the publisher or author. 


\title{
FARM-LEVEL PESTICIDE USE IN BANGLADESH: DETERMINANTS AND
} AWARENESS ${ }^{1}$

\author{
Sanzidur Rahman \\ Research Fellow \\ School of Economic Studies \\ University of Manchester \\ Manchester, UK
}

\section{Address for Correspondence}

\section{Sanzidur Rahman}

School of Economic Studies

The University of Manchester

Oxford Road

Manchester, M13 9PL

England, UK

Phone: (0161) 2754865

Fax: (0161) 2754812

E-mail: Sanzidur.Rahman@man.ac.uk

April 2002

(Revised version following final comment of the editor)

\footnotetext{
${ }^{1}$ The present paper is developed from the author's Ph.D. dissertation, which was completed at the Asian Institute of Technology (AIT), Bangkok, Thailand in 1998.
} 


\title{
FARM-LEVEL PESTICIDE USE IN BANGLADESH: DETERMINANTS AND AWARENESS
}

\begin{abstract}
Farmers' awareness of beneficial and harmful effects of pesticides and factors determining use of pesticides were analyzed using survey data from 21 villages in three agro-ecological regions of Bangladesh. Pesticide cost accounts for about 7.7 percent of the gross value of output in cotton, 3.6 percent in vegetables, 2.5 percent in potato, 1.8 percent in modern rice, 1.6 percent in spices and less than one percent in other cereal and non-cereal crops. About 77 percent of farmers (highest 94 percent in Comilla) used pesticides at least once (37 percent applied once and 31 percent applied twice, and the rest applied between three to five times) in a crop season. Cultivation of traditional and modern rice varieties, potatoes, spices, vegetables and cotton are the prime determinants of pesticide use. Farmers seem to treat pesticides as substitutes for fertilizers, indicated by the positive influence of fertilizer prices on pesticide use. Also, increases in pulse and jute prices increase pesticide use. Among the socio-economic variables, land ownership and agricultural credit are positively related to pesticide usage. Pesticide use is higher in underdeveloped regions. Sharp regional variations also exist in pesticide usage. Major policy thrusts for devising pesticide regulation and effective implementation, increasing farmers' awareness of the effects of pesticide use, and expansion of IPM practices are suggested to safeguard poor farmers in their pursuit of agricultural livelihoods.
\end{abstract}

KEY WORDS: Pesticide use, multivariate analysis, farmers' awareness, Bangladesh. 


\section{FARM-LEVEL PESTICIDE USE IN BANGLADESH: DETERMINANTS AND}

\section{AWARENESS}

\section{INTRODUCTION}

Farmers use a wide range of pesticides to prevent crop loss from pest attack. Use of pesticides in crop production has spread rapidly worldwide since the 1950s with an estimated annual compound growth rate of 4.4 percent during the period 1993-98 in the Asia/Oceania region (Yudelman et al., 1998). Although use of pesticides as well as crop loss due to pests are increasing globally, a marginal increase in pesticide use still appears to be profitable to farmers (Yudelman et al., 1998).

Emergence of pest resistance to pesticides is one of the major negative aspects of pesticide use, compounded by a widespread claim that chemicals are harmful to human health and the environment (Pingali, 1995; Antle and Pingali, 1994; Rola and Pingali, 1993). There is widespread acceptance that expansion of modern agricultural technologies led to sharp increase in pesticide use (Roger and Bhuiyan, 1995; Pingali and Rola, 1995). Therefore, with the increased diffusion of 'green revolution' technology in regions of Asia, Latin America and Africa, pesticides became and will continue to be a major component of modern day agriculture.

Pesticide use in Bangladesh, negligible until the 1970s, has recorded a dramatic rise in recent years. Pesticide use levels increased from 2,200 metric tons in 1980-82 to 6,500 metric tons in 1992-94 and modern rice cultivation increased from 20.3 percent of total rice area to 49.0 percent during the same period (Rahman and Thapa, 1999).

Studies on factors determining demand for major inputs, such as labor, fertilizer and irrigation for crop production owing to the 'green revolution' in Bangladesh are numerous (Rahman, 2000; Rahman and Routray, 1998; Ahmed and Sampath, 1992; Ahmed and Hossain, 
1990; Alauddin and Tisdell, 1991; Hossain, 1989; Hossain et al., 1990). However, similar information on pesticide use, which has become an essential input in crop production, is not available. The present study, therefore, attempts to contribute to the existing body of literature by explicitly examining the factors determining the use of pesticides and farmers' awareness of beneficial and harmful effects of pesticides.

\section{MATERIALS AND METHODS}

\section{The data}

The study is based on farm-level cross section data for crop year 1996 collected from three agro-ecological regions of Bangladesh. The survey was conducted from February to April 1997. The specific selected regions were Jamalpur (representing wet agroecology), Jessore (representing dry agroecology), and Comilla (representing both wet agroecology and an agriculturally developed area). Multistage random sampling technique was employed to locate the districts, then the thana (subdistricts), then the villages in each of the three subdistricts and finally the sample households. A total of 406 households from 21 villages (175 households from eight villages of Jamalpur Sadar thana, 105 households from six villages of Manirampur thana and 126 households from seven villages of Matlab thana) form the sample for the study. Detailed crop input-output data were collected for ten crop groups ${ }^{2}$. The dataset also includes information from soil samples from representative locations and information on infrastructural facilities.

\footnotetext{
${ }^{2}$ The crop groups are: traditional rice varieties (Aus - pre-monsoon, Aman - monsoon, and Boro - dry seasons), modern/high yielding rice varieties (Aus, Aman, and Boro seasons), modern/high yielding wheat varieties, jute, potato, pulses, spices, oilseeds, vegetables, and cotton. Pulses in turn include lentil, mungbean, and gram. Spices include onion, garlic, chilly, ginger, and turmeric. Oilseeds include sesame, mustard, and groundnut. Vegetables include eggplant, cauliflower, cabbage, arum, beans, gourds, radish, and leafy vegetables.
} 


\section{Theoretical framework}

To examine the determinants of pesticides demand for producing various crops, a model based on profit maximizing behaviour of farmers is utilized. Evidence of profit maximizing behaviour of Bangladeshi farmers is well established (e.g., Hossain, 1989, Hossain et al., 1990, and Ahmed and Hossain, 1990).

Assume for simplicity that there are two variable input vectors: pesticides, Q and 'other inputs', $\mathrm{O}$, and one fixed input, $\mathrm{L}$ that is allocated between various crops $\left(\mathrm{L}_{\mathrm{i}}\right.$ being the allocation to the ith crop). These are used to produce n number of crops $(i=1 \ldots n)$.

Producer j maximizes total profits:

$\sum_{i=1}^{n} p_{i} Y_{i j}-w^{Q} Q_{j}-w^{O} O_{j}$

s.t. $Y_{i j}=f\left(Q_{i j}, O_{i j}, L_{i j}, S_{j}\right)$ for $\mathrm{i}=1 \ldots \mathrm{n}$

and $\sum_{i=1}^{n} L_{i j} \leq L_{j}$

where $Q_{j}=Q_{l j}+\ldots .+Q_{n j}$

and $\quad O_{j}=O_{1 j}+\ldots .+O_{n j}$

Equation (1) is an individual production function for each crop i. It depends on pesticide application to that crop, 'other variable inputs' applied to that crop, land allocated to that crop, and a set of exogenous variables, $S_{j}$ that shift the production function. $Y$ 's are output quantities, p's and w's are output prices and input prices. Equation (2) simply states that land allocated to various crops must be less than the total land cultivated by the producer.

The first order conditions will lead to the corresponding demand functions for pesticides and for 'other inputs' for individual crops:

$Q_{j}=Q_{j}\left(w^{Q}, w^{O}, p_{1} \ldots p_{n}, L_{1 j} \ldots, L_{n j}, S_{j}\right)$ 
$O_{j}=O_{j}\left(w^{Q}, w^{O}, p_{1} \ldots p_{n}, L_{1 j} \ldots, L_{n j}, S_{j}\right)$

We can aggregate the pesticide demand functions of individual crops as follows:

$$
Q_{j}^{\prime}=Q_{j}^{\prime}\left(w^{Q}, w^{O}, p_{1} \ldots p_{n}, L_{1 j} \ldots, L_{n j}, S_{j}\right)
$$

The assumption of the separability of inputs (pesticide on one hand, and all 'other inputs' on the other) enables the pesticide demand equation to be estimated separately ${ }^{3}$. Observe that the arguments appearing in the aggregate pesticide demand function are the vector of input prices, output prices, and a set of exogenous factors.

\section{Econometric model}

The application of usual continuous techniques (for example, Ordinary Least Squares) in this setting will result in biased and inconsistent estimates since input data are censored at zero and cannot be negative. The Tobit model provides a suitable method for estimating the pesticide demand equation in this case, as it allows for zero use of inputs ${ }^{4}$.

The Tobit model is specified as:

$Q_{j}^{\prime}{ }^{*}=Q_{j}^{\prime}\left(\left(w^{Q}, w^{O}, p_{1} \ldots p_{n}, L_{l j} \ldots, L_{n j}, S_{j}\right)+\mathrm{u}_{\mathrm{j}}\right.$

$Q_{j}^{\prime}{ }_{j}^{*}$ being a latent variable such that:

$Q_{j}{ }_{j}=Q^{\prime}{ }^{*}$ if $Q^{\prime}{ }_{j}^{*}>0$

$Q_{j}^{\prime}=0$ if $Q_{j}^{\prime}{ }^{*} \leq 0$

\footnotetext{
${ }^{3}$ Individual estimation of factor demand functions utilizing separability assumption has been widely used in empirical studies, such as, Beneito et al., (2001), Dey (2000), Ahmed and Hossain (1990), Hossain et al., (1990), and Hossain (1989).

${ }^{4}$ Estimation of demand and/or determinant functions using the Tobit model has been widely used when the dependent variable contains zero observations, such as, Beneito et al., (2001), Dey (2000), Rahman (2000), Rahman, (1999). Thapa et al., (1992), Hossain et al., (1990) and Hossain (1989).
} 
where the disturbances $\mathrm{u}_{\mathrm{j}}$ is an error term and is independent and identically distributed as $\mathrm{N}(0$, $\left.\sigma^{2}\right)$

The list of variables included in the pesticide demand function was: (a) input prices includes price of pesticide ( $\mathrm{taka}^{5} / 100 \mathrm{ml}$ or gm), price of fertilizer (taka/kg), labour (taka/personday), and animal power (taka/pair-day); (b) output prices in taka/kg - includes prices of traditional rice, modern/HYV (high yielding variety) rice, modern/HYV wheat, jute, potatoes, pulses, oilseeds, spices, vegetables and cotton; (c) amount of land allocated to various crops in hectares - crops include traditional rice, modern/HYV rice, modern/HYV wheat, jute, potatoes, pulses, oilseeds, spices, vegetables and cotton; (d) a set of socio-economic characteristics which include total land area owned by the producer in hectares, percent of cultivated area under irrigation, amount of agricultural loan in thousands of taka, level of education of the producer (completed years of schooling), level of soil fertility ${ }^{6}$, and level of underdevelopment of infrastructure ${ }^{7}$; and (e) regional dummy variables. Amount of pesticide per farm in $100 \mathrm{ml}$ or gm

\footnotetext{
${ }^{5}$ Exchange rate: 1 US dollar $=42.7$ Taka (approximately) during 1996-97 (BBS, 1997).

${ }^{6}$ Information on physical and chemical properties of soil from the selected farmers' fields were collected to evaluate the general fertility status of the soil and to examine inter-regional differences (if any) between the study areas. Ten soil-fertility parameters were tested. These were: (1) soil $\mathrm{pH},(2)$ available nitrogen, (3) available potassium, (4) available phosphorus, (5) available sulfur, (6) available zinc, (7) soil texture, (8) cation exchange capacity (CEC) of soil, (9) soil organic matter content, and (10) electrical conductivity of soil. The soil fertility index was constructed from test results of these soil samples. High index value refers to better soil fertility.

7 The index of infrastructure was constructed using the cost of access approach. A total of 13 elements were considered for its construction. These are, (1) primary market, (2) secondary market, (3) storage facility, (4) rice mill, (5) paved road, (6) bus stop, (7) bank, (8) union office, (9) agricultural extension office, (10) high school, (11) college, (12) thana (sub-district) headquarter, and (13) post office. High index value refers to high under developed infrastructure.
} 
was specified as the dependent variable ${ }^{8}$.

Fertilizers, labour and animal power, are the three major inputs that are essential in producing any crop and contribute significantly to the total cost of production. Profit maximizing farmers are expected to respond and/or adjust their input use levels to changes in the prices of these three major inputs and are hence included in the demand function.

Prices of outputs have direct bearing on the gross revenue earned from producing individual crops. Therefore, producers are expected to respond to changes in the output prices.

Producers allocate different amounts of land to each crop in a cropping system. Also, different crops have different types and frequencies of pest infestation ${ }^{9}$. Therefore, the influence of an individual crop on pesticide use cannot be determined a priori, although a positive association with certain crops is expected. Because of this, land allocated to each crop is incorporated in the model to capture their individual influences on pesticide use.

In Bangladesh, land ownership serves as a surrogate for a large number of factors as it is a major source of wealth and influences crop production. A positive association between various factor inputs (such as labor, both hired and family supplied, fertilizers, irrigation, etc.) and land ownership is established in various studies (Rahman, 2000; Hossain, 1989; Ahmed and Hossain, 1990; Hossain et al., 1990). However, explicit association of pesticide use and land ownership has not been determined in these studies. The land ownership variable is incorporated to test its influence on pesticide use. A positive coefficient for this variable implies that large farmers use more pesticides than the poor marginal farmers.

\footnotetext{
${ }^{8}$ Pesticides here refer mainly to insecticides of various groups.

${ }^{9}$ In fact, Bangladeshi farmers currently apply a certain dosage of pesticides at the primary stage of the production cycle as a precautionary measure for certain crops of high market value. Subsequent application, thereafter, depends on intensity of pest/disease infestation.
} 
Access to irrigation opens up an opportunity to adopt modern agricultural technology as well as diversify cropping patterns. The proportion of area under irrigation was incorporated to capture its effect on pesticide use.

The availability of cash may be a determining factor, enabling the producer to purchase pesticide as required. An agricultural credit variable was incorporated to capture this effect.

The state of infrastructure, in terms of better transportation and marketing facilities would affect prices (cost of pesticide in this case) through transport costs and the profit margins of traders. The prices farmers pay for inputs and receive for outputs include this transportation cost. Also traders' margins are likely to vary across farms and regions, depending on the state of development of infrastructure. This effect was captured by the index of infrastructural underdevelopment variable.

Higher soil fertility status implies favorable physical conditions for agricultural production. This in turn would influence the demand for inputs (including pesticides). Therefore the soil fertility factor was incorporated to capture the effect of soil quality on pesticide use.

The education variable was used as a surrogate for a number of factors. At the technical level, access to information and the ability to utilize inputs (in this case pesticides) optimally may influence crop production decisions.

Regional dummies were incorporated to capture variation across regions, if any.

\section{RESULTS}

\section{Basic characteristics of the study regions}

Jamalpur is located within Jamalpur Sadar Thana (central administrative sub-district) which in turn is located in the southeastern part of Jamalpur district. The study area is about 11 
$\mathrm{km}$ by road from district headquarters and $182 \mathrm{~km}$ northwest from the capital Dhaka. Jessore is located in Manirampur Thana in the southern part of Jessore district. The study area is about 20 $\mathrm{km}$ by road from district headquarters and $294 \mathrm{~km}$ southwest from Dhaka. Comilla is located in Matlab Thana in the southeastern part of Chandpur district. The study area is about $18 \mathrm{~km}$ by road from Chandpur district headquarters and $120 \mathrm{~km}$ southeast from Dhaka (Figure 1).

\section{[INSERT MAP HERE]}

Comilla has the lowest amount of owned land per household ( $0.53 \mathrm{ha})$ while Jessore has the highest $(0.90 \mathrm{ha})$, followed by Jamalpur $(0.80 \mathrm{ha})$. The family size for these three regions are 7.0, 6.7 and 5.4 persons/household, respectively.

The highest proportion of modern technology diffusion is in Jamalpur, with 75 percent of the land under modern varieties of rice and wheat, and 59 percent of the land under irrigation during the crop year 1996. The area under cultivation with modern varieties in Jessore is 56 percent and in Comilla 59 percent. The area under irrigation for these two regions is 59 percent and 47 percent, respectively.

Rice of all varieties in all three seasons (Aus, Aman and Boro season, respectively) constitutes 80 percent of the gross cropped area, while the remaining 20 percent is allocated to wheat and non-cereal cash crops. The cropping intensity ${ }^{10}$ of the sample households is estimated at 172.8 (183.3 in Jamalpur, 178.2 in Jessore and 148.2 in Comilla region), which is very close to the national estimate of 179.2 for the crop year 1992/93 (BBS, 1996).

\section{Pesticide use rates in crops}

Use of pesticides in crops is dependent upon disease prevalence, pest infestations and the

\footnotetext{
${ }^{10}$ Cropping intensity is defined as the ratio of gross cropped area to net sown area multiplied by 100.
} 
type of crops grown. Although, in the past, pesticides were rarely applied in local rice crops, use rates have substantially increased since the introduction of modern varieties of rice. Also, pesticide usage became necessary for non-cereal crops. The large expense incurred for pesticides in modern rice, vegetables, potato and cotton is evidence for this increase in use (Table 1). There are sharp inter-regional differences in pesticide usage for crops. Comilla region, with its poor soil quality, and intensive rice monoculture, uses pesticides intensively when compared to other regions (Table 1).

\section{[INSERT TABLE 1 HERE]}

The mean level of pesticide use in Comilla (Tk. 633 per hectare) was more than double that of Jamalpur (Tk. 240 per hectare), while the use rate in Jessore was between these two (Tk. 404 per hectare). The factor share of pesticides at the mean level was quite low, ranging from 0.8 percent to 2.4 percent of gross value of output. However, it rose to as high as 7.7 percent of gross value of output in cotton, $3.6-4.5$ percent in vegetables and about 2.6 percent in potato production. For modern rice varieties in Comilla, pesticide costs accounted for an estimated 4.2 percent of gross value of output, which is high.

Few studies explicitly report the usage of pesticides. Because of this, comparisons of the change in rate of pesticide use remain limited. However, it can be confidently stated that the current level of pesticide use is much higher than previous levels, as reflected in the dramatic increase in the consumption of pesticides across these regions over time, while the net cultivable 
area under crop remained more or less unchanged ${ }^{11}$.

\section{Frequency of pesticide application}

About 77 percent of farmers (highest 94 percent in Comilla) applied pesticides at least once in a crop season (Table 2). Although about half of the farmers in Jamalpur and Jessore applied pesticides only once in a crop season, 63 percent of Comilla farmers applied twice. Furthermore, 22 percent of farmers in Comilla region applied as many as $3-5$ times in a crop season, indicating a relatively higher incidence of pest and insect attack in that region when compared to Jamalpur and Jessore.

\section{[INSERT TABLE 2 HERE]}

\section{Pesticide supply source}

The source of pesticide supply is mainly from secondary markets (growth centers) in the rural regions. Few farmers in Jamalpur reported the city market as their primary source (Table 3). However, an inquiry into the distances of buying places of pesticides revealed that the majority of farmers can buy their pesticides within three kms from their villages. About 41 percent of them reported that the distance of pesticide buying place is within one km, implying

\footnotetext{
${ }^{11}$ The annual growth rate of pesticide use during a 17-year period $(1977-1993)$ was estimated at 10.4 percent in Jessore, 9.3 percent in Jamalpur, 4.6 percent in Comilla, and 8.6 percent in Bangladesh as a whole (Hamid, 1991; BBS, 1979 to 1997). On the other hand, the net cropped area in Bangladesh declined from 8.53 million hectares in 1980-82 to 7.81 million hectares in 1992-94, although cropping intensity increased from 153.6 to 176.0. The total rice area, however, also declined slightly from 10.3 million hectares to 10.1 million hectares during the same period, with a shift from local/traditional varieties to modern/high yielding varieties (Rahman and Thapa, 1999).
} 
widespread availability of pesticides and negligible transport costs incurred for pesticide purchases.

\section{[INSERT TABLE 3 HERE]}

\section{Farmers' perception of effects of pesticide use}

Farmers' opinions were elicited by posing open questions on their perception of the effects of insecticide use. All farmers were first asked to provide their opinion of the beneficial effects of insecticide use. Next, they were asked to provide opinions on any harmful effects of pesticide use.

The major beneficial effect of pesticide/insecticide use as perceived by farmers was ‘destruction of insects' (39.2 percent) and consequent 'increase in production' (24.4 percent) with sharp regional variation in opinion (Table 4). 'Preventing disease infestation' is also cited by 16.7 percent of farmers. Only few (3.4 percent) link it to 'requiring less fertilizer'.

\section{[INSERT TABLE 4 HERE]}

When asked whether they consider pesticides to have any harmful effects, the majority (42.4 percent) responded that it 'does not affect much', implying that although they are aware of the adverse effects, the benefits outweigh the harm (Table 5). The distribution of this particular opinion was very diverse. About 62.9 percent of farmers in Jessore considered that harmful effects of pesticides were not critical, as compared with only 19.0 percent of Comilla farmers, who use high levels of pesticides.

[INSERT TABLE 5 HERE] 
About 6.9 percent of farmers in Jamalpur link the use of pesticides to a 'bitter taste for the product', particularly the rice crop. The awareness of the 'health effect' of pesticide use was 16.7 percent in Comilla while it was negligible and nil in Jamalpur and Jessore, respectively. Similar results were found for awareness of effects on fish. An awareness of effects on 'animal health' was also evident in Comilla and Jamalpur regions. It is evident from Table 5 that the perception of farmers of harmful impacts of pesticides use was stronger and more widespread in Comilla, where farmers use more of these pesticides, probably over a longer period of time.

Questions about the present level of pesticide application revealed that 23 percent of farmers in Jamalpur and Jessore regions are considering either increasing or ceasing use of pesticides, while 81 percent of Comilla farmers consider their present use rate as appropriate. A large majority (66 - 95 percent) of farmers consider that they use a sufficient amount of pesticides for their crops.

\section{Determinants of pesticide use}

Table 6 presents the parameter estimates of the pesticide demand function as well as the marginal effects of each variable ${ }^{12}$ on pesticide use ${ }^{13}$. Results suggest that producers treat fertilizers as substitute to pesticides. Rise in fertilizer price significantly increases pesticide use. Increase in pesticide price reduces its demand, consistent with the expectation.

Among the output prices, jute and pulses significantly increase pesticide use. The current application rate of pesticides to these two crops is at the minimum. This is perhaps due to the fact that the relative profitability of pulses and jute is lowest among non-cereals (Rahman, 1998).

\footnotetext{
${ }^{12}$ The summary statistics of the variables are presented in Appendix Table A1.

${ }^{13}$ LIMDEP Software Version 7 (1997) was used for the analysis.
} 
Therefore, increase in the prices of jute and pulses would induce them to use increased level of inputs (including pesticides) in an attempt to boost their crop yield levels and to generate higher revenue.

Production of traditional rice, modern/HYV rice, potatoes, spices, vegetables and cotton significantly increases pesticide use. Therefore, the influence of modern agricultural technology (area under modern varieties of rice) in increasing pesticide use remains undisputed.

Examination of the size of coefficients for crop areas clearly reveals that the incremental effect of pesticide use is much higher in cotton, vegetables and spices followed by potatoes as compared to traditional and modern/HYV rice.

Land ownership is significantly positively associated with pesticide use indicating that large farm households use more pesticides, consistent with expectation ${ }^{14}$.

The availability of cash, approximated by the agricultural credit variable, is significantly positively related with pesticide use, indicating that greater liquidity increases use rates.

The influence of soil fertility level is not prominent. This is because the soil fertility levels in all three regions are relatively poor.

\footnotetext{
${ }^{14}$ The main source of this positive association is the increase in cropped area as the farm size increases with rise in land size classes, reconfirmed by a significantly positive correlation between land owned and pesticide use $(r=0.40$, $\mathrm{p}<0.01)$. However, the mean application rate of pesticides per hectare of cropped area is not significantly different across land size classes due to wide variation in application rate within each category. As a whole, the mean pesticide application rate per hectare of cropped area of the large farms is estimated at 12 - 14 percent higher than the small and medium sized farms and 6 percent lower than the marginal farms.
} 
The influence of infrastructural development is prominent. The significant positive coefficient on this variable indicates that pesticide use is higher in underdeveloped regions. Pesticide use is significantly higher in Comilla region, which was also shown in Table 1.

\section{[INSERT TABLE 6 HERE]}

\section{DISCUSSION AND POLICY IMPLICATIONS}

Pesticide use has become an important factor in modern agriculture. Results revealed that the cost of pesticide use is quite high for cotton, vegetables, potato, modern rice varieties and spices. Furthermore, the rapid growth in pesticide use over time, nationwide, is alarming. Pesticide use is significantly higher in traditional and modern rice, potato, spice, vegetable and cotton production. This has profound implications for agricultural sustainability. On the one hand, over the past four decades, the major thrust of national policy has been to promote 'green revolution' technology that has resulted in a consequent increase in pesticide use in addition to other modern inputs. On the other hand, the non-governmental organizations (NGOs), such as BRAC (Bangladesh Rural Advancement Committee), Proshika, and ASA (Association of Social Advancement), are promoting kitchen gardening (as a measure to alleviate poverty) to increase household income and agricultural production for poor landless women, mainly through vegetable production. For example, BRAC's vegetable extension network covers an estimated 25,000 villages nationwide (RDP, 1999). A recent study on pesticide use levels on such BRAC organized poor farms also revealed an alarming scenario. The estimated cost of pesticide use in vegetables is Tk. 1,346 per hectare, in hybrid maize is Tk. 1,223 per hectare, and in modern 
varieties of rice is Tk. 827 per hectare (Rahman et al., 2000). Also, a substantial portion of these farmers (about 41 percent) used pesticides that are banned (largely organophosphates).

Farmers seem to treat pesticides as substitutes for fertilizers. The price of fertilizers is on the rise in Bangladesh following the liberalization of the fertilizer market and removal of subsidy since 1992. Therefore, the effect of rise in fertilizer price would be to induce additional incremental effects on pesticide use. Also, increases in jute and pulse prices have a significant positive influence on pesticide use, indicating that a boost in these prices would also induce increased use of pesticides.

Results also revealed that increased access to agricultural credit significantly influences pesticides use as it opens up opportunities for diversifying crop production and/or for increased cropping intensity. Increasing irrigated area as well as increased disbursement of agricultural credit are also priority policy thrusts of the government, in the continuing effort to raise agricultural productivity and the standard of living for the poor masses.

This discussion is not designed to challenge promotional policies which are essential components in raising agricultural productivity and the standard of living of Bangladeshi people. Rather it is intended to identify the potential threats that will accompany these developments and the need for some urgency in devising appropriate strategies to tackle the situation. In this context, increased importance should be given to devise pesticide regulatory policies and ensure effective implementation. For example, the ‘dirty dozen' pesticides, banned worldwide, including Bangladesh, are being used indiscriminately by farmers even today (Motin, 2000).

Also, farmers' awareness of the harmful effects of pesticides is not very strong, as revealed in this study, as they find that beneficial effects outweigh any harmful ones. Therefore, a priority policy option should be to utilize the existing agricultural extension network, including 
those operated by NGOs, to incorporate awareness training on the harmful effects of pesticide use and to train farmers in proper handling and management practices. This will reduce the adverse effects of increased pesticide use as a result of increased adoption of modern agricultural technology and/or diversified cropping systems. Currently, the thrust of the existing agricultural extension networks is to promote modern technology adoption and use of modern inputs (such as, chemical fertilizers, irrigation, and pesticides) with no emphasis on harmful impacts.

Integrated pest management (IPM) practices at a limited scale are being implemented by the Department of Agricultural Extension with technical help from the Food and Agricultural Organization of the United Nations and is considered highly successful (Deliberation by Agricultural Minister in the National Assembly meeting, 2001). The problem of such pilot projects is that their expansion is limited to funding availability, which is always a major constraint for developing nations such as Bangladesh. Also, a few NGOs, such as CAREBangladesh and Proshika, are promoting IPM technologies in selected operational areas. However, detailed information on the success of these projects is not widely available. Nevertheless, experience in various regions suggests that IPM practices can significantly reduce pesticide use without reducing yields. For example, CARE International helped maize farmers in Nicaragua to reduce pesticide use by 70 percent in a single year without changing yields (Hruska 1995, cited in Yudelman et al., 1998). The FAO-supported IPM programs for rice in Indonesia, initiated since $1980 \mathrm{~s}$, in combination with pesticide regulatory policies, led to a reduction of pesticide use by 65 percent during 1987 to 1990 while rice yields increased by approximately 12 percent (Yudelman et al., 1998).

Therefore, a combination of pesticide regulatory policies, programs to raise farmers' awareness of the harmful effects of pesticides, and a commitment to promote IPM practices (by 
government as well as NGOs) may safeguard poor farmers in their pursuit of increased agricultural production and a resulting increase in income and standard of living.

ACKNOWLEDGEMENTS: The author is grateful to Bhavani Shankar and the anonymous referees for valuable suggestions and comments. The author alone is responsible for remaining errors. 


\section{REFERENCES}

Ahmed, A.U., Sampath, R.K., 1992. Effects of irrigation-induced technological change in Bangladesh rice production. American Journal of Agricultural Economics 74, 144-157.

Ahmed, R., Hossain, M., 1990. Developmental Impact of Rural Infrastructure in Bangladesh. Research Report. No.83. International Food Policy Research Institute, Washington, D.C.

Antle, J.M., Pingali, P.L., 1994. Pesticides, productivity and farmer health: a Philippine case study. American Journal of Agricultural Economics 76, 418-430.

Alauddin, M., Tisdell, C., 1991. The Green Revolution and Economic Development: The Process and its Impact in Bangladesh. Macmillan, London.

BBS, 1979. Statistical Yearbook of Bangladesh, 1979. Bangladesh Bureau of Statistics, Dhaka.

BBS, 1980. Statistical Yearbook of Bangladesh, 1980. Bangladesh Bureau of Statistics, Dhaka.

BBS, 1981. Statistical Yearbook of Bangladesh, 1981. Bangladesh Bureau of Statistics, Dhaka.

BBS, 1989. Statistical Yearbook of Bangladesh, 1989. Bangladesh Bureau of Statistics, Dhaka.

BBS, 1991. Statistical Yearbook of Bangladesh, 1991. Bangladesh Bureau of Statistics, Dhaka. 
BBS, 1992. Statistical Yearbook of Bangladesh, 1992. Bangladesh Bureau of Statistics, Dhaka.

BBS, 1994. Statistical Yearbook of Bangladesh, 1994. Bangladesh Bureau of Statistics, Dhaka.

BBS, 1996. Statistical Yearbook of Bangladesh, 1995. Bangladesh Bureau of Statistics, Dhaka.

BBS, 1997. Statistical Yearbook of Bangladesh, 1996. Bangladesh Bureau of Statistics, Dhaka.

Beneito, P., Ferri, J., Molto, M.L., Uriel, E., 2001. Determinants of the demand for education in Spain. Applied Economics 33, 1541-1551.

Dey, M.M., 2000. Analysis of demand for fish in Bangladesh. Aquaculture Economics and Management 4, 65-83.

Hamid, M.A., 1991. A Database on Agriculture and Foodgrains in Bangladesh (1947/48 1989/90). Bangladesh Agricultural Research Council/ Winrock International, Dhaka.

Hossain, M., 1989. Green Revolution in Bangladesh: Impact on Growth and Distribution of Income. University Press Limited, Dhaka.

Hossain, M., Quasem, M.A., Akash, M.M., Jabber, M.A., 1990. Differential Impact of Modern Rice Technology: The Bangladesh Case. Bangladesh Institute of Development Studies, Dhaka. 
Motin, R., 2000. Stark realities of pesticide use. Dhaka Courier 16, 18-19.

Pingali, P.L., 1995. Impact of pesticides on farmer health and the rice environment: an overview of results from a multidisciplinary study in the Philippines. In: Pingali, P.L., Roger, P. (Eds.), Impact of Pesticides on Farmer Health and the Rice Environment. Kluwer Academic Publishers, Boston.

Pingali, P.L., Rola, A.C., 1995. Public regulatory roles in developing markets: the case of Philippines. In: Pingali, P.L., Roger, P. (Eds.), Impact of Pesticides on Farmer Health and the Rice Environment. Kluwer Academic Publishers, Boston.

Rahman, S., 1998. Socio-economic and environmental impacts of technological change in Bangladesh agriculture. Unpublished Ph.D. Dissertation. Asian Institute of Technology, Bangkok.

Rahman, S., 1999. Impact of technological change on income distribution and poverty in Bangladesh agriculture: an empirical analysis. Journal of International Development 11, 935955.

Rahman, S., 2000. Women's employment in Bangladesh agriculture: composition, determinants and scope. Journal of Rural Studies 16, 497-507.

Rahman, S., Routray, J.K., 1998. Technological change and women's participation in crop production in Bangladesh. Gender, Technology and Development 2, 243-267. 
Rahman, S., Thapa, G.B., 1999. Environmental impact of technological change in Bangladesh agriculture: farmers' perception and empirical evidence. Outlook on Agriculture 28, 233-238.

Rahman, S., Hossain, M.Z., Sharmin, L., 2000. Cumulative environmental effects assessment of BRAC's agriculture, fisheries and poultry program. Research and Evaluation Division, BRAC, Dhaka.

RDP, 1999. RDP IV Report to Donors, July - December, 1999. BRAC, Dhaka.

Roger, P.A., Bhuiyan, S.I., 1995. Behavior of pesticides in rice-based agro-ecosystems: a review. In: Pingali, P.L., Roger, P. (Eds.) Impact of Pesticides on Farmer Health and the Rice Environment. Kluwer Academic Publishers, Boston.

Rola, A.C., Pingali, P.L., 1993. Pesticides, Rice Productivity and Farmers’ Health: An Economic Assessment. International Rice Research Institute, Los Banos and The World Resources Institute, Washington, D.C.

Thapa, G., Otsuka, K., Barker, R., 1992. Effect of modern rice varieties and irrigation on household income distribution in Nepalese villages. Agricultural Economics 7, 245-265.

Yudelman, M., A. Ratta, D. Nygaard., 1998. Pest Management and Food Production: Looking to the Future. Food, Agriculture, and the Environment Discussion Paper 25. International Food Policy Research Institute, Washington, D.C. 
Table 1. Pesticide use rates and share in gross value of output.

\begin{tabular}{|c|c|c|c|c|c|c|c|c|}
\hline \multirow[t]{3}{*}{ Crops } & \multicolumn{4}{|c|}{ Pesticides use rates (taka/ha) } & \multicolumn{4}{|c|}{$\begin{array}{l}\text { Pesticides cost as share of gross value } \\
\text { of output (percent) }\end{array}$} \\
\hline & \multicolumn{2}{|c|}{ Jamalpur Jessore } & \multirow{2}{*}{$\begin{array}{l}\text { Comilla } \\
\text { region }\end{array}$} & \multirow{2}{*}{$\begin{array}{l}\text { All } \\
\text { region }\end{array}$} & \multicolumn{2}{|c|}{ Jamalpur Jessore } & \multirow{2}{*}{$\begin{array}{l}\text { Comilla } \\
\text { region }\end{array}$} & \multirow{2}{*}{$\begin{array}{l}\text { All } \\
\text { region }\end{array}$} \\
\hline & region & region & & & region & region & & \\
\hline \multicolumn{9}{|l|}{ Foodgrain } \\
\hline Local rice & 44.8 & 121.4 & 170.6 & 109.6 & 0.33 & 0.88 & 0.83 & 0.60 \\
\hline Modern rice & 182.2 & 396.6 & $1,022.3$ & 438.9 & 0.70 & 1.62 & 4.21 & 1.78 \\
\hline Mod. wheat & 85.8 & 12.6 & 77.7 & 55.7 & 0.51 & 0.09 & 0.35 & 0.29 \\
\hline \multicolumn{9}{|l|}{ Non-cereals } \\
\hline Jute & 71.3 & 123.2 & 0.0 & 77.7 & 0.33 & 0.57 & 0.00 & 0.36 \\
\hline Potato & $1,028.8$ & 94.1 & $1,346.8$ & $1,159.1$ & 2.56 & 0.45 & 2.60 & 2.47 \\
\hline Pulses & $\mathrm{Ng}$ & 23.2 & 0.0 & 19.6 & ng & 0.21 & 0.00 & 0.18 \\
\hline Oilseeds & 0.0 & 9.9 & 130.0 & 37.0 & 0.00 & 0.09 & 1.05 & 0.59 \\
\hline Spices & $1,045.6$ & 0.0 & 0.0 & 622.9 & 2.61 & 0.00 & 0.00 & 1.55 \\
\hline Vegetables & 497.5 & $1,687.1$ & ng & $1,389.7$ & 1.05 & 4.47 & ng & 3.61 \\
\hline Cotton & $\mathrm{Ng}$ & $1,926.2$ & ng & $1,926.2$ & ng & 7.71 & ng & 7.71 \\
\hline All crops & 240.2 & 404.4 & 632.7 & 404.5 & 0.81 & 1.50 & 2.44 & 1.49 \\
\hline
\end{tabular}

Note: Total number of observations is 1,448 comprising of 117 local rice, 829 modern rice, 103 modern wheat, 92 jute, 59 potato, 70 pulses, 47 spices, 44 vegetables and 16 cotton.

ng means not grown.

1 US Dollar = 42.7 Taka (approximately) during 1996-97 (BBS, 1997).

Source: Field Survey, 1997. 
Table 2. Number of applications of pesticides in a crop season.

\begin{tabular}{|c|c|c|c|c|}
\hline \multirow{3}{*}{$\begin{array}{l}\text { Number of applications of } \\
\text { pesticides }\end{array}$} & \multicolumn{4}{|c|}{ Percent of farmers $(\%)$} \\
\hline & Jamalpur & Jessore & Comilla & All \\
\hline & region & region & region & region \\
\hline Farmers applying pesticides & $\underline{67.4}$ & $\underline{73.3}$ & $\underline{94.4}$ & $\underline{77.3}$ \\
\hline One time & 46.3 & 54.3 & 10.3 & 37.2 \\
\hline Two times & 17.7 & 16.2 & 62.7 & 31.3 \\
\hline Three times & 2.8 & 2.8 & 14.3 & 6.4 \\
\hline Four times & 0.6 & - & 4.0 & 1.5 \\
\hline Five times & - & - & 3.1 & 0.9 \\
\hline Farmers not applying pesticides & $\underline{32.6}$ & $\underline{26.7}$ & $\underline{5.6}$ & $\underline{22.7}$ \\
\hline Total & 100.0 & 100.0 & 100.0 & 100.0 \\
\hline Mean number of applications & 0.93 & 0.95 & 2.10 & 1.30 \\
\hline Standard deviation & 0.82 & 0.74 & 0.95 & 1.00 \\
\hline Total farmers/farm households & 175 & 105 & 126 & 406 \\
\hline
\end{tabular}

Source: Field Survey, 1997. 
Table 3. Buying place of pesticides and average distance.

\begin{tabular}{|c|c|c|c|c|}
\hline \multirow[t]{2}{*}{ Buying place of pesticides } & \multicolumn{4}{|c|}{ Percent of farmers $(\%)$} \\
\hline & $\begin{array}{l}\text { Jamalpur } \\
\text { region }\end{array}$ & $\begin{array}{l}\text { Jessore } \\
\text { region }\end{array}$ & $\begin{array}{l}\text { Comilla } \\
\text { region }\end{array}$ & All region \\
\hline \multicolumn{5}{|l|}{ Buying place of pesticides } \\
\hline Primary market (within the village) & - & - & 1.6 & 0.5 \\
\hline Secondary market (growth centers) & 86.8 & 100.0 & 98.4 & 93.8 \\
\hline City market & 13.12 & - & - & 5.7 \\
\hline \multicolumn{5}{|l|}{ Distance of buying place of pesticides } \\
\hline Less than one $\mathrm{km}$ & 37.7 & 30.5 & 55.6 & 41.4 \\
\hline Between one to three $\mathrm{kms}$ & 46.3 & 65.7 & 44.4 & 50.7 \\
\hline More than three kms & 16.0 & 3.8 & - & 7.9 \\
\hline Total & 100.0 & 100.0 & 100.0 & 100.0 \\
\hline Total farmers/ farm households & 175 & 105 & 126 & 406 \\
\hline
\end{tabular}

Source: Field Survey, 1997. 
Table 4. Farmers' perception on beneficial effects of pesticide use.

\begin{tabular}{lllll}
\hline Farmers' perception on beneficial Percent of farmers (\%) & & \\
\cline { 2 - 5 } effects of pesticides & Jamalpur & Jessore & Comilla & All \\
& region & region & region & region \\
\hline Destroy insects & 31.4 & 36.2 & 52.4 & 39.2 \\
\hline Increases production & 22.9 & 11.4 & 37.3 & 24.4 \\
\hline Prevents disease infestation & 22.9 & 25.7 & 0.8 & 16.7 \\
\hline Good plant growth & 4.0 & 0.9 & 6.3 & 3.9 \\
\hline Require less fertilizer & 3.4 & 6.7 & 0.8 & 3.4 \\
\hline Non-responding farmers & 15.4 & 19.0 & 2.4 & 12.3 \\
\hline Total & & & & 100.0 \\
\hline Total farmers/ farm households & 175 & 100.0 & 100.0 & 406 \\
\hline
\end{tabular}

Source: Field Survey, 1997. 
Table 5. Farmers' perception on harmful effects of pesticide use.

\begin{tabular}{|c|c|c|c|c|}
\hline \multirow{3}{*}{$\begin{array}{l}\text { Farmers' perception on harmful } \\
\text { effects of pesticides }\end{array}$} & \multicolumn{4}{|c|}{ Percent of households (\%) } \\
\hline & Jamalpur & Jessore & Comilla & All \\
\hline & region & region & region & region \\
\hline Do not affect much & 46.9 & 62.9 & 19.0 & 42.4 \\
\hline Damages plants if used in excess & 4.0 & 5.7 & 20.6 & 9.6 \\
\hline Affects human health & 2.3 & - & 16.7 & 6.2 \\
\hline Cause fish destruction & 0.6 & - & 16.7 & 5.4 \\
\hline Cause death of livestock/poultry & 4.6 & 0.9 & 7.9 & 4.7 \\
\hline Tasteless product & 6.9 & 0.9 & - & 3.2 \\
\hline Production falls if used in excess & - & 0.9 & 8.7 & 2.9 \\
\hline Destroys soil fertility & 1.1 & 0.9 & 1.6 & 1.2 \\
\hline Pollutes water body & - & - & 2.4 & 0.7 \\
\hline Non-responding farmers & 33.7 & 27.6 & 6.3 & 23.6 \\
\hline Total & 100.0 & 100.0 & 100.0 & 100.0 \\
\hline Total farmers/ farm households & 175 & 105 & 126 & 406 \\
\hline
\end{tabular}

Source: Field Survey, 1997. 
Table 6. Determinants of pesticide use.

\begin{tabular}{lllll}
\hline Variables & \multicolumn{3}{l}{ Dependent variable: Amount of pesticides used per farm } \\
\cline { 2 - 5 } & Coefficient & t-ratio & \multicolumn{2}{l}{ Marginal effects t-ratio } \\
\hline Constant & -22.7869 & -0.844 & -18.5866 & -0.844 \\
\hline Input prices & & & & \\
\hline ln Pesticide price & -1.6992 & $-2.405^{* * *}$ & -1.3860 & $-2.408^{* * *}$ \\
\hline ln Fertilizer price & 4.4981 & $4.244^{* * *}$ & 3.6689 & $4.250^{* * *}$ \\
\hline $\ln$ Animal power price & 0.5695 & 0.583 & 0.4645 & 0.582 \\
\hline $\ln$ Labor wage & 1.9473 & 1.335 & 1.5884 & 1.336 \\
\hline
\end{tabular}

\section{Output prices}

\begin{tabular}{lllll}
\hline ln Traditional rice price & 1.0102 & 0.378 & 0.8240 & 0.378 \\
\hline ln Modern rice price & 3.1668 & 1.540 & 2.5831 & 1.541 \\
\hline ln Modern wheat price & 1.4983 & 0.817 & 1.2221 & 0.816 \\
\hline ln Jute price & 3.1883 & $2.134^{* *}$ & 2.6006 & $2.134^{* *}$ \\
\hline ln Potato price & 0.3237 & 0.301 & 0.2641 & 0.301 \\
\hline $\ln$ Pulse price & 10.4688 & $4.467^{* * *}$ & 8.5390 & $4.466^{* * *}$ \\
\hline $\ln$ Oilseed price & -1.5201 & -1.184 & -1.2399 & -1.183 \\
\hline ln Spice price & -1.2537 & -0.664 & -1.0226 & -0.671 \\
\hline ln Vegetable price & -0.3414 & -0.438 & -0.2785 & -0.438 \\
\hline $\ln$ Cotton price & -8.8272 & -1.154 & -7.2000 & -1.154 \\
\hline Area cultivated & & & & \\
\hline Traditional rice area & 1.1448 & $1.940^{*}$ & 0.9338 & $1.941^{*}$ \\
\hline
\end{tabular}




\begin{tabular}{|c|c|c|c|c|}
\hline Modern rice area & 0.9725 & $3.544 * * *$ & 0.7932 & $3.541 * * *$ \\
\hline Modern wheat area & -0.6804 & -0.414 & -0.5550 & -0.413 \\
\hline Jute area & -1.4162 & -0.719 & -1.1551 & -0.719 \\
\hline Potato area & 6.0406 & $2.211 * *$ & 4.9271 & $2.213 * *$ \\
\hline Pulse area & 2.4427 & 1.145 & 1.9924 & 1.145 \\
\hline Oilseed area & -1.7419 & -0.848 & -1.4208 & -0.848 \\
\hline Spice area & 13.1040 & $2.732 * * *$ & 10.6885 & $2.731 * * *$ \\
\hline Vegetable area & 14.7727 & $4.526 * * *$ & 12.0496 & $4.514 * * *$ \\
\hline Cotton area & 19.3974 & $4.249 * * *$ & 15.8218 & $4.239 * * *$ \\
\hline \multicolumn{5}{|l|}{ Socioeconomic characteristics } \\
\hline ln Total land owned & 0.2546 & $2.423 * * *$ & 0.2077 & $2.424 * * *$ \\
\hline Percent of area under irrigation & 0.8135 & 1.293 & 0.6636 & 0.513 \\
\hline Amount of agricultural loan & 0.1587 & $4.483 * * *$ & 0.1294 & $4.424 * * *$ \\
\hline Level of education & -0.0155 & -0.367 & -0.0126 & -0.367 \\
\hline Soil fertility & -1.3255 & -0.669 & -1.0812 & -0.669 \\
\hline Infrastructure & 0.0609 & $3.022 * * *$ & 0.0497 & $3.021 * * *$ \\
\hline Comilla region dummy & 4.9935 & $3.875 * * *$ & 4.0731 & $3.882 * * *$ \\
\hline Jamalpur region dummy & -0.3628 & -0.310 & -0.2959 & -0.310 \\
\hline Log-likelihood & $-1071.902 * * *$ & & & \\
\hline
\end{tabular}

Note: $\quad * * *$ Significant at $1 \%$ level $(\mathrm{p}<0.01)$,

** Significant at 5\% level $(\mathrm{p}<0.05)$,

* Significant at $10 \%$ level $(\mathrm{p}<0.10)$. 


\section{APPENDIX}

Appendix Table A1. Summary statistics of the variables used in the analysis.

\begin{tabular}{lll}
\hline Variables & Mean & Standard Deviation \\
\hline Pesticide quantity $(100 \mathrm{ml}$ or gm) & 3.474 & 4.71 \\
\hline Input prices & & 15.69 \\
\hline Pesticide price (taka/100 ml or gm) & 83.141 & 1.31 \\
\hline Fertilizer price (taka/kg) & 5.967 & 17.34 \\
\hline Animal power price (taka/pair-day) & 83.556 & 8.22 \\
\hline Labor wage (taka/person-day) & 44.673 & \\
\hline Output prices (taka/kg) & & 0.45 \\
\hline Traditional rice price & 5.452 & 1.52 \\
\hline Modern rice price & 5.462 & 1.14 \\
\hline Modern wheat price & 7.905 & 1.12 \\
\hline Jute price & 9.579 & 0.86 \\
\hline Potato price & 3.845 & 1.92 \\
\hline Pulse price & 18.482 & \\
\hline Oilseed price & & \\
\hline Spice price & & \\
\hline Vegetable price & & \\
\hline & & \\
\hline
\end{tabular}




\begin{tabular}{|c|c|c|}
\hline Cotton price & 23.474 & 0.74 \\
\hline \multicolumn{3}{|l|}{ Area cultivated (ha) } \\
\hline Traditional rice area & 0.090 & 0.28 \\
\hline Modern rice area & 0.689 & 0.78 \\
\hline Modern wheat area & 0.046 & 0.12 \\
\hline Jute area & 0.046 & 0.13 \\
\hline Potato area & 0.016 & 0.06 \\
\hline Pulse area & 0.038 & 0.14 \\
\hline Oilseed area & 0.030 & 0.11 \\
\hline Spice area & 0.008 & 0.04 \\
\hline Vegetable area & 0.012 & 0.06 \\
\hline Cotton area & 0.008 & 0.04 \\
\hline \multicolumn{3}{|l|}{ Socioeconomic characteristics } \\
\hline Total land owned (ha) & 0.653 & 0.77 \\
\hline Percent of area under irrigation (\%) & 0.616 & 0.30 \\
\hline Amount of agricultural loan ('000 taka) & 2.578 & 11.95 \\
\hline Level of education (years) & 3.739 & 4.26 \\
\hline Soil fertility index & 1.677 & 0.19 \\
\hline Infrastructure index & 33.322 & 14.95 \\
\hline
\end{tabular}

Source: Field Survey, 1997. 